\title{
ANALISIS KESULITAN SISWA DALAM MENANGANI PERMASALAHAN MATEMATIKA TERBUKA (MATHEMATIC OPEN-ENDED PROBLEMS)
}

\author{
${ }^{1}$ I Putu Ade Andre Payadnya, ${ }^{2}$ I Gusti Agung Ngurah Trisna Jayantika \\ Program Studi Pendidikan Matematika FKIP Unmas Denpasar \\ Program Studi Pendidikan Matematika IKIP PGRI Bali \\ e-mail:ade_andre2805@yahoo.com
}

\begin{abstract}
ABSTRAK
Penelitian ini bertujuan untuk: 1) menganalisis kesulitan siswa dalam menangani permasalahan matematika terbuka, 2) menganalisis pelaksanaan pembelajaran matematikayang sudah berlangsung. Subjek dalam penelitian adalah seluruh siswa Kelas VIII A8 SMP Negeri 1 Singaraja yang berjumlah 28 orang. Metode pengumpulan data yang digunakan dalam penelitian ini adalah metode observasi, tes, dan wawancara. Teknik analisis data dalam penelitian ini menggunakan analisis deskriptif kualitatif yang menganalisis dan menjabarkan berbagai hasil temuan terkait kesulitan siswa dalam menangani permasalahan matematika terbuka. Hasil penelitian yang diperoleh dari analisis terhadap jawaban siswa, wawancara, dan observasi menunjukkan bahwa kesulitan siswa dalam menangani permasalahan matematika terbuka meliputi: 1) kurangnya pemahaman siswa terhadap permasalahan matematika terbuka, 2) kurangnya kemampuan siswa dalam melakukan reasoning dimana siswa hanya melakukan reasoning yang tidak efektif seperti dengan cara coba-coba dalam menentukan ukuran, 3) kesulitan siswa dalam menentukan metode lain yang dapat digunakan dalam menyelesaikan permasalahan, 4) kurangnya kemampuan representasi dan berpikir secara riil siswa dalam menyelesaikan permasalahan agar siswa dapat memikirkan cara terbaik dalam menyelesaikan masalah matematika terbuka. Saran yang dapat diberikan peneliti adalah agar guru-guru mata pelajaran matematika dapat menekankan pada aspek pemahaman konsep dan aspek pengembangan kemampuan berpikir dalam melakukan pembelajaran di kelas.
\end{abstract}

Kata kunci: permasalahan matematika terbuka, analisis deskriptif kualitatif, pemahaman, reasoning

\section{ABSTRACT}

This research aimed at: 1) analyzing the students' difficulty on solving mathematic open-ended problems, 2) analyzing the implementation of conducted mathematic's learning. Subjects of the study was the whole grade VIII A8 students in SMP Negeri 1 Singaraja with the total number was 28 students. The data collection methods used in this research were observation, test, and interview. The technique of data analysis in this study made use qualitative descriptive analysis that was to analyze and describe every problem and difficulty that students faced when solving mathematic open-ended problems. The results from the test, interview, and observation analysis showed that the students' difficulty on solving mathematic open-ended problems are:1) the students' lack of ability on understanding mathematic open-ended problems, 2)the students had poor reasoning ability in which the students usually is a non-effective reasoning, 3) the stdudents'lack of representation ability and real thinking ability on solving the problems so that the students cannot find the best method to solve the problems. The researcher's advise is that the mathematic teachers have to point on conceptual understanding and thinking ability development when teaching mathematics subject on classes. 
Key words: mathematic open-ended problems, qualitative descriptive analysis, understanding, reasoning

\section{PENDAHULUAN}

Pembelajaran matematika dewasa ini sudah mengalami berbagai perkembangan yang signifikan.Pengembangan yang dilakukan sangat erat kaitannya dengan kemampuan berpikir siswa. Paradigma pendidikan sekarang mengharuskan siswa membiasakan berpikir secara kritis dalam menyelesaikan suatu permasalahan. Karena alasan tersebut, dikembangkan suatu permasalahan yang berorientasi pada pengembangan kemampuan berpikir siswa yang disebut sebagai masalah matematika terbuka. Hal ini didukung oleh Cifarelli dan Cai (2005) yang menyatakan bahwa dalam menyelesaikan masalah matematika terbuka, ide baru dapat dikembangkan dan dieksplorasi tanpa paksaan dan akan mengembangkan kemampuan berpikir siswa.

Menurut Sudiarta (2005) yang mengutip dari Shimada, permasalahan terbuka (masalah matematika terbuka) adalah suatu permasalahan yang mempunyai banyak solusidan banyak cara atau penyelesaian. Melalui masalah matematika terbuka, siswa diajarkan untuk berpikir secara berbeda dan tidak tunggal. Siswa dibiasakan untuk memandang suatu permasalahan secara luas dengan mengidentifikasi berbagai kemungkinan. Pembelajaran dengan pendekatan terbuka diawali dengan memberikan masalah terbuka kepada siswa. Kegiatan pembelajaran harus mengarah dan membawa siswa dalam menjawab masalah dengan banyak cara serta dengan banyak jawaban (yang benar), sehingga merangsang kemampuan intelektual dan pengalaman siswa dalam proses menemukan sesuatu yang baru.

Permasalahan matematika terbuka atau mathematic open-ended problems merupakan permasalahan yang disajikan untuk dapat meningkatkan daya berpikir siswa sehingga siswa mampu memahami berbagai konsep matematika dengan lebih baik. Permasalahan matematika terbuka dapat merangsang pemikiran kreatif dan divergen siswa, serta membuat siswa dapat menganalisis lebih dalam suatu permasalahan dan berpikir dengan lebih kritis dalam menyelesaikan permasalahan tersebut. Hal ini menyebabkan terjadinya peningkatan dalam daya berpikir siswa. Siswa yang memiliki daya berpikir yang tingga akan mampu dengan baik menyelesaikan permasalahan rutin maupun non rutin sehingga siswa dapat memiliki kemampuan matematika yang baik. Siswa yang terlatih berpikir terbuka juga akan memiliki sikap dan nilai yang baik dalam melihat suatu permasalahan dimana siswa dapat melihat permasalahan yang dihadapi dari berbagai sudut pandang dan tidak akan terburu-buru dalam mengambil keputusan.

Pentingnya kemampuan siswa dalam menangani permasalahan ternyata tidak didukung oleh tingkat kemampuan siswa. Penelitian yang dilakukan oleh Clarke, dkk (1992) menunjukkan bahwa pemahaman siswa terhadap masalah matematika terbuka masih kurang. Siswa kebanyakan kurang familiar dengan masalah matematika terbuka yang menyebabkan siswa kesulitan dalam menangani masalah matematika terbuka. Clarke juga 
mengungkapkan bahwa siswa cenderung kesulitan menemukan lebih dari satu caramaupun jawaban dalam meresponmasalah matematika terbuka. Clarke menyimpulkan bahwa permasalahan ini harus dipelajari lebih lanjut dan dicarikan solusinya. Selain itu, permasalahan siswa dalam menyelesaikan masalah matematika terbuka juga dikemukakan oleh Sullivan, dkk (2000). Dalam penelitiannya, Sullivan menemukan bahwa kebanyakan siswa menganggap masalah matematika terbuka jauh lebih sulit dari permasalahan biasa dan siswa kesulitan dalam menanganinya. Lowrie, dkk (2000) mengungkapkan bahwa siswa terbiasa menjawab permasalahan rutin yang biasanya hanya mengarah pada satu cara dan solusi sehingga menyebabkan kemampuan siswa dalam menyelesaikan masalah matematika terbuka menjadi terbatas. Siswa sulit untuk mencerna dan menerima masalah matematika terbuka karena pola pikir awal yang dimiliki siswa terpaku pada permasalahan yang bersifat tunggal.

Menurut Brousseau (1997), pada praktiknya siswa secara alamiah mengalami situasi yang disebut hambatan belajar atau yang dikenal dengan learning obstacle. Hal ini disebabkan oleh tiga faktor, yaitu hambatan ontogeni (kesiapan mental belajar), hambatan didaktis (pengajaran guru atau bahan ajar), dan epistemologis (pengetahuan siswa yang memiliki konteks aplikasi yang terbatas). Beberapa kesalahan umum yang dilakukan oleh siswa yang berkesulitan dalam belajar matematika adalah kekurangan pemahaman tentang simbol, nilai tempat, perhitungan, penggunaan proses yang keliru dan tulisan yang tidak terbaca. Sedangkan kesalahan siswa dalam mengerjakan matematika merupakan kesalahan dasar, kesalahan dalam pemahaman soal, kesalahan dalam pengambilan keputusan dan kesalahan dalam hal perhitungan.

Kemampuan siswa dalam menangani permasalahan terbuka juga mengalami bayak hambatan. Dengan adanya permasalahan tersebut, maka perlu dilakukan suatu penelitian untuk menganalisis kesulitan yang dihadapi siswa dalam menangani permasalahan matematika terbuka. Penelitian ini penting dilakukan agar dapat mengetahui apa saja hambatan yang dihadapi siswa dalam menangani permasalahan matematika terbuka. Penelitian ini mengambil subjek penelitian pada siswa Kelas VIII SMP Negeri 1 Singaraja, Bali. Penelitian ini akan menyajikan analisis deskriptif kualitatif tentang kemampuan siswa dalam menangani permasalahan matematika terbuka.

\section{METODE}

Rancangan penelitian dalam penelitian ini adalah penelitian deskriptif kualitatif, yaitu penelitian yang berusaha untuk mendeskripsikan suatu gejala peristiwa atau kejadian secara sistematis sesuai dengan keadaan yang ada di dalam suatu populasi(Dantes, 2012). Agung (2014) menyatakan bahwa penelitian deskriptif bisa mendeskripsikan suatu keadaan saja, tetapi bisa juga mendeskripsikan keadaan dalam tehapantahapan perkembangan. Sehingga penelitian ini mendeskripsikan kesulitan siswa Kelas VIII SMP Negeri 1 Singaraja dalam menangani permasalahan matematika terbuka. Kelas yang terpilih untuk menjadi subjek penelitian adalah kelasVIII A8 SMP Negeri 1 Singaraja dengan banyak siswa 28 orang. Untuk memperoleh data tentang analisis kesulitan 
siswa dalam menangani permasalahan matematika terbuka. Waktu penelitian adalah Semester II Tahun Pelajaran 2015/2016. Penentuan tempat dan waktu ini disesuaikan berdasarkan kebutuhan maksud dan tujuan dari penelitian ini. Jenis data yang dikumpulkan dari sampel penelitian adalah data primer. Agung (2014) mengatakan data primer adalah data yang diperoleh dari sumber pertama atau yang diperoleh secara langsung dari sumber pertama. Data ini diperoleh sendiri dari hasil pengukuran, wawancara dan observasi. Dalam penelitian ini, data primer diperoleh melalui jawaban tes tertulis, wawancara dan observasi yang dilakukan kepada siswa dan guru mengenai kemampuan menyelesaikan soal cerita matematika. Metode pengumpulan data dalam penelitian ini adalah observasi, tes, dan wawancara. Tes dapat diartikan sebagai suatu metode penelitian psikologis untuk memperoleh informasi tentang berbagai aspek tingkah laku dengan penggunaan pengukuran (measurement) yang menghasilkan suatu deskripsi kuantitatif tentang aspek yang diteliti. Wawancara adalah pertemuan dua orang untuk bertukar informasi dan ide melalui tanya jawab, sehingga dapat dikonstruksikan makna dalam suatu topik tertentu (Sugiyono, 2013). Observasi dimaksudkan untuk melakukan pengamatan secara langsung terhadap subjek yang di selidiki secara cermat, kemudian dilanjutkan dengan mencatat hal-hal yang dianggap penting untuk memperkuat keakuratan data Instrumen penelitian berkaitan dengan kegiatan pengumpulan dan pengolahan informasi/data. Instrumen yang digunakan dalam penelitian ini adalah tes uraian, pedoman wawancara dan pedoman observasi.
Untuk mengetahui kesulitan siswa dalam menangani permasalahan matematika terbuka diberikan tes diagnosis permasalahan matematika terbuka yang berbentuk uraian dengan materi luas daerah lingkaran. Hasil tes akan dianalisis secara mendalam untuk mempeoleh hasil yang berupa deretan kesulitan yang dihadapi siswa. Untuk mengetahui kendala kendala-kendala yang dihadapi siswa dan memperkuat hasil analisis tes dilakukan wawancara dengan guru dan siswa terkait kasulitan yang dihadapi siswa dan kendala-kendala dalam pembelajaran. Untuk mengetahui pelaksanaan pembelajaran matematika pada kelas yang dijadikan subjek penelitian dilakukan observasi kepada guru mata pelajaran matematika, untuk mengetahui apa saja yang dilakukan guru pada saat membelajarkan matematika di kelas. Hasil tes, wawancara, dan observasi kemudian digabungkan untuk memperoleh kesimpulan umum mengenai kesulitan yang dihadapi siswa dalam menangani permasalahan matematika terbuka.

\section{HASIL DAN PEMBAHASAN}

Peneliti memberikan tes kepada siswa berupa 5 buah permasalahan matematika terbuka (mathematic openended problems) pada materi luas daerah lingkaran. Tes ini dikerjakan oleh siswa Kelas VIII A8 SMP Negeri 1 Singaraja. Hasil jawaban siswa kemudian dikumpulkan dan dianalisis secara mendalam untuk dapat menemukan kesulitan yang dihadapi siswa dalam menangani permasalahan matematika terbuka. Berikut adalah hasil analisis terhadap permasalahan matematika terbuka.

\section{Soal no 1}


Masalah pertama adalah mengenai menggambar lingkaran dengan luas daerah yang ditentukan. Bunyi dari soal no 1 adalah "Gambarlah dua buah lingkaran dengan luas daerah berada diantara 0 $\mathrm{cm}^{2}$ dan $200 \mathrm{~cm}^{2}$ !".

Dalam menjawab permasalahan ini, kebanyakan siswa tidak melakukan atau menyertakan reasoning yang sesuai. Reasoning yang dimaksud adalah menyertakan alasan yang dapat berupa perhitungan maupun konsep yang akan memperkuat jawaban. Siswa menggambar lingkaran saja dengan suatu ukuran jarijari atau diameter tertentu. Namun tidak menyertakan perhitungan yang dapat menjadi alasan mengapa lingkaran yang dibuat memenuhi syarat. Hal ini disebabkan karena siswa yang terbiasa menjawab permasalahan dengan mengedapkan pemahaman prosedural sehingga siswa bingung saat akan melakukan reasoning pada masalah matematika terbuka. Mengingat beragamnya jawaban yang dapat dihasilkan dari penyelesaian masalah matematika terbuka, reasoning merupakan poin penting untuk memperkuat jawaban yang diberikan. Contoh jawaban siswa yang tidak menyertakan reasoning adalah sebagai berikut.

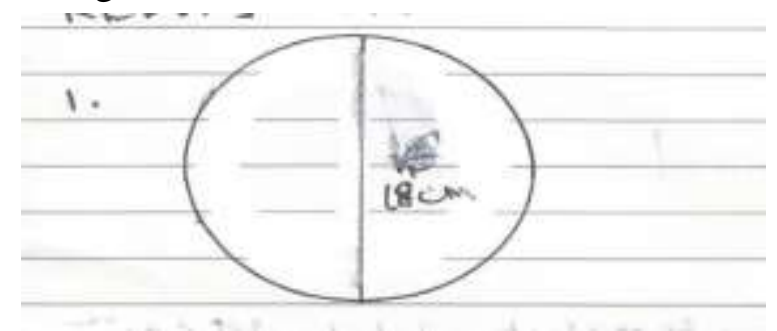

Gambar 1. Jawaban Siswa

Selain contoh di atas, banyak juga siswa yang hanya sekedar menggambarkan dua buah lingkaran tanpa ukuran jari-jari ataupun diameter, dan ada juga siswa yang menggambarkan lingkaran dan sekedar menuliskan luas daerah kedua lingkaran tersebut agar memenuhi syarat yang diinginkan. Hal ini menggambarkan kurangnya pemahaman siswa terhadap masalah matematika terbuka. Berikut adalah contoh jawaban siswa yang dimaksud.

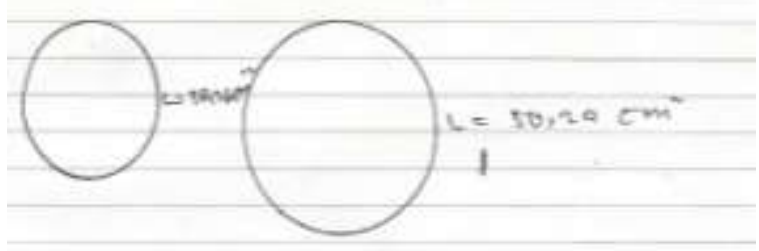

Gambar 2. Jawaban siswa

\section{Soal No 2}

Pada soal no 2, permasalahan berfokus pada menentukan jari-jari dari lingkaran baru dengan syarat luas daerah dari lingkaran baru tidak kurang dari $\frac{1}{4}$ luas daerah lingkaran lama. Soal no 2 adalah "Anton mempunyai karton berbentuk lingkaran dengan jari-jari $10 \mathrm{~cm}$, jika Andi ingin punya karton dengan luas tidak kurang dari $\frac{1}{4}$ luas karton Anton, berapakah jari-jari karton Andi?".

Dalam menjawab permasalahan no 2 ini, kebanyakan siswa kurang memahami permasalahan yang disajikan. Dalam permasalahan ini siswa bebas memilih luas daerah lingkaran yang diinginkan asalkan tidak kurang dari $\frac{1}{4}$ luas daerah lingkaran lama. Namun, pada kenyataannya hampir semua siswa memilih luas daerah lingkaran baru $\frac{1}{4}$ dari luas daerah lingkaran lama. Siswa tidak menyadari kemungkinan dapat memilih luas daerah lingkaran baru dengan nilai $\frac{1}{3}$ atau $\frac{1}{2}$ luas daerah lingkaran lama. Contoh jawaban siswa yang dimaksud adalah sebagai berikut. 


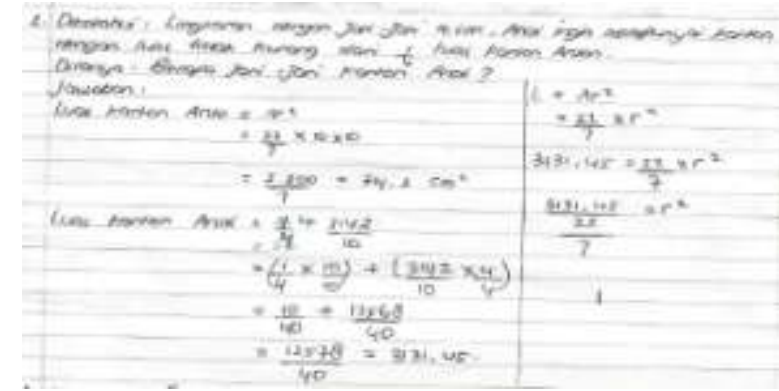

Gambar 3. Jawaban Siswa

Selain itu, banyak terjadi kurangnya reasoning dalam jawaban siswa. Siswa banyak yang memilih ukuran jari-jari lingkaran tertentu tanpa menyertakan alasan kenapa dipilih ukuran tersebut. Contoh dari jawaban siswa yang dimaksud disajikan dalam gambar berikut ini.

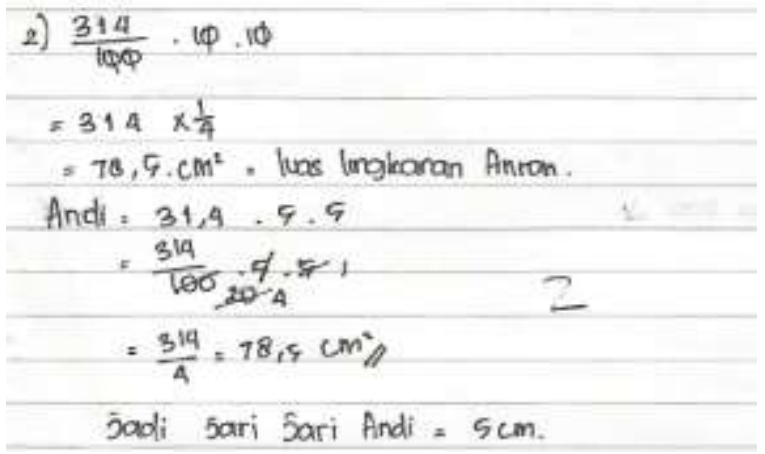

Gambar 4. Jawaban Siswa

\section{Soal No 3}

Dalam soal no 3, disajikan permasalahan yang berkaitan dengan penerapan konsep luas daerah lingkaran serta luas daerah bangun datar lainnya dalam kehidupan sehari-hari. Dalam hal ini, siswa diminta untuk menentukan luas sisa dari seng berbentuk persegi yang digunakan untuk membuat tutup kaleng berbentuk lingkaran. Soal no 3 adalah "Selembar seng berbentuk persegi berukuran $20 \mathrm{~cm}$ x $20 \mathrm{~cm}$. Dengan seng tersebut akan dibentuk tutup-tutup kaleng berbentuk lingkaran. Jika akan dibuat tutup kaleng sebanyak mungkin, luas seng yang tidak digunakan adalah?".
Dalam menjawab permasalahan ini, diperlukan kreativitas serta kecermatan siswa dalam menentukan ukuran tutup kaleng yang mungkin dan sesuai. Pada dasarnya, siswa bebas untuk menentukan ukuran tutup kaleng asalkan rasional. Namun, menentukan ukuran diameter maupun jari-jari tutup kaleng harus disertakan dengan bukti yang mendukung serta dapat menjelaskan secara pasti seberapa banyak tutup kaleng yang dapat dibuat. Dalam hal ini, kebanyakan siswa secara asal menentukan banyak tutup kaleng yang dapat dibuat setelah ditentukan ukurannya. Siswa hampir semua berpikir, banyak tutup kaleng yang dapat dibuat bebas asalkan jumlah luasnya masih kurang dari luas seng. Padahal jika diterapkan secara nyata, ada keterbatasan banyak tutup kaleng yang dapat dibuat karena mengikuti ukuran dari seng yang disajikan. Bisa saja sisa seng masih melebihi luas 1 tutup kaleng namun sudah tidak dapat dibentuk tutup kaleng lagi. Hal ini mencirikan kurangnya kemampuan siswa dalam melakukan reasoning. Contoh jawaban siswa yang dimaksud adalah sebagai berikut.

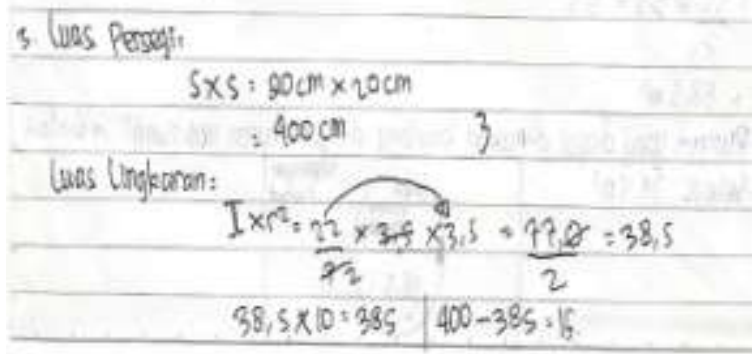

Gambar 5. Jawaban Siswa

Dalam menjawab soal ini, sangat diperlukan penggambaran atau representasi agar jawaban yang dibuat tepat, terutama dalam menentukan banyaknya tutup kaleng yang dibuat. Namun, kebanyakan siswa menjawab soal ini tanpa menyertakan representasi yang 
sesuai sehingga menyebabkan kesalahan pada jawaban siswa.

\section{Soal No 4}

Pada soal no 4,difokuskan pada keterkaitan dan penerapan konsep keliling lingkaran dengan luas daerah lingkaran dalam kehidupan sehari-hari. Soal no 4 adalah "Sebuah balok kayu digelindingkan satu putaran penuh dan ternyata hampir menempuh jarak 88 $\mathrm{cm}$, berapakah luas permukaan balok kayu tersebut?".

Pada soal no 4, terlihat jelas kurangnya pemahaman siswa terhadap soal. Semua siswa tidak ada menjawab dengan tepat permasalahan ini. Hampir semua siswa bahkan tidak memiliki ide yang tepat dalam menjawab permasalahan ini. Dalam menjawab soal ini, siswa hanya terpaku dan terhenti sampai memperoleh jari-jari ataupun diameter dari balok kayu dan tidak mencari apa yang diinginkan soal yaitu luas penampang dari balok kayu tersebut. Siswa juga tidak memanfaatkan kemampuan berpikir divergen dan kreatif dengan baik karena hampir semua siswa mencari jari-jari dan diameter lingkaran dengan menggunakan nilai keliling lingkaran $88 \mathrm{~cm}$. Padahal yang seharusnya adalah keliling lingkaran kurang dari 88 cm karena sudah ditegaskan dalam soal bahwa balok kayu hampir menempuh jarak $88 \mathrm{~cm}$ setelah digelindingkan satu putaran penuh. Contoh jawaban siswa yang dimaksud disajikan dalam gambar berikut ini.

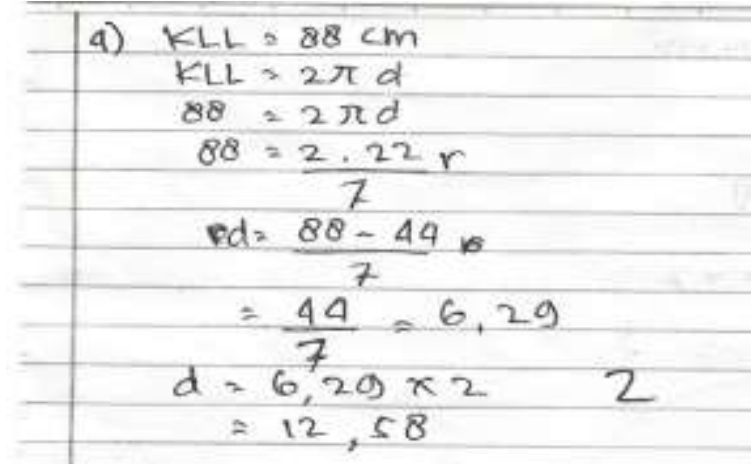

Gambar 6. Jawaban Siswa

\begin{tabular}{|c|c|c|}
\hline \multicolumn{3}{|c|}{ 4). Misakan Dimeter lingkaron $=28 \quad r=18$} \\
\hline$k i=\pi \times d$ & $L_{\text {WuS }}=\pi \times \Gamma \times r$ & 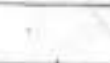 \\
\hline$P P=\frac{12}{7} \times 28$ & $=22 x+314$ & $1+$ \\
\hline$x+2 x+4$ & 71 & $2+27$ \\
\hline$k i=88$ & $=44 \times 14$ & 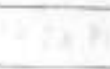 \\
\hline $72+2+2 x+4$ & $=616 \mathrm{cos}$ & $v_{3}$ \\
\hline
\end{tabular}

Gambar 7. Jawaban Siswa

Pada soal no 4 ini, terlihat banyak jawaban siswa yang jauh dari harapan atau jawaban yang diinginkan. Banyak terjadi kesalahan-kesalahan pemahaman siswa terhadap soal dan banyak juga siswa yang tidak menjawab.

\section{Soal no 5}

Soal no 5 merupakan soal yang merupakan perwujudan dari pemanfaatan kemampuan berpikir divergen, kritis, dan kreatif siswa dalam menyelesaikan permasalahan yang berkaitan dengan luas daerah lingkaran pada kasus yang dapat dibilang kompleks. Soal no 5 adalah: "Seorang petani melepas seekor kambing pada sebuah lapangan penuh rumput dengan panjang 21 m dan lebar 7 m seperti pada gambar di bawah ini. Petani tersebut mempunyai 2 buah tali patok dengan panjang $1 \mathrm{~m}$ dan $3,5 \mathrm{~m}$. Dengan memanfaatkan salah satu atau kedua tali tersebut, berapa $m^{2}$ kah maksimal rumput yang dapat dimakan kambing? Gambarkanlah area makan 
serta perpindahan yang dilakukan pak tani terhadap kambing tersebut!"

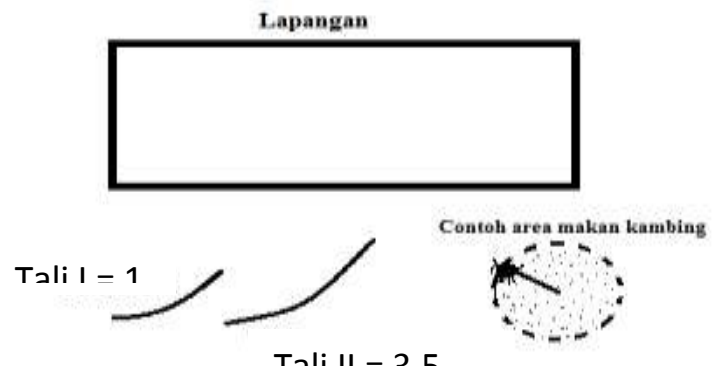

Gambar 8. Ilustrasi

Pada soal no 5, banyak siswa yang tidak memanfaatkan kemampuan berpikir secara divergen maupun kreatif. Dalam menjawab permasalahan ini, siswa tidak memanfaatkan kedua tali dengan baik. Siswa tidak bisa menggambarkan pemanfaatan tali tersebut secara maksimal agar kambing dapat memakan rumput semaksimal mungkin. Siswa cenderung hanya menggunakan satu tali dan hanya melakukan satu perpindahan sehingga sisa rumput yang tidak dimakan oleh kambing menjadi sangat luas. Hal ini mencirikan kurang pahamnya siswa dengan masalah matematika terbuka, terkait dengan maksud serta bagaimana cara penyelesaian dari permasalahan tersebut. Contoh jawaban yang dimaksud adalah sebagai berikut ini.

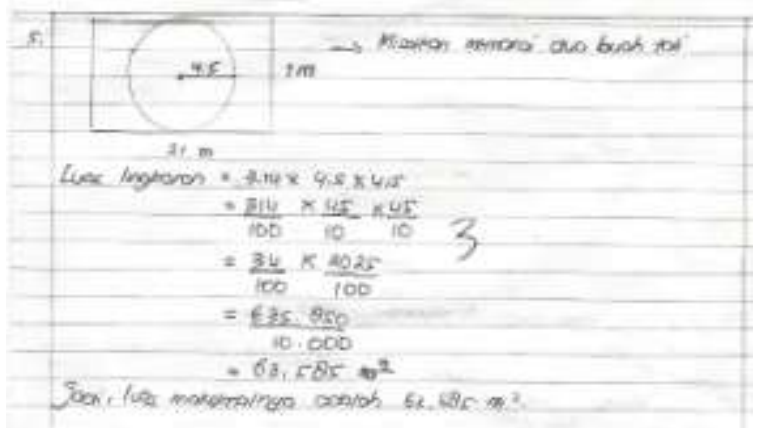

Gambar 9. Jawaban Siswa

Ada juga jawaban yang unik dari siswa yang belum pernah diprediksi sebelumnya oleh peneliti. Jawaban yang dimaksud dimana siswa memanfaatkan kedua tali tersebut dengan menyambungkan kedua tali sehingga diperoleh tali sepanjang 4,5 m. Namun, masih banyak kesalahan dalam jawaban siswa terutama dalam hal pemanfaatan dan penggambarannya. Contoh jawaban siswa tersebut adalah sebagai berikut.

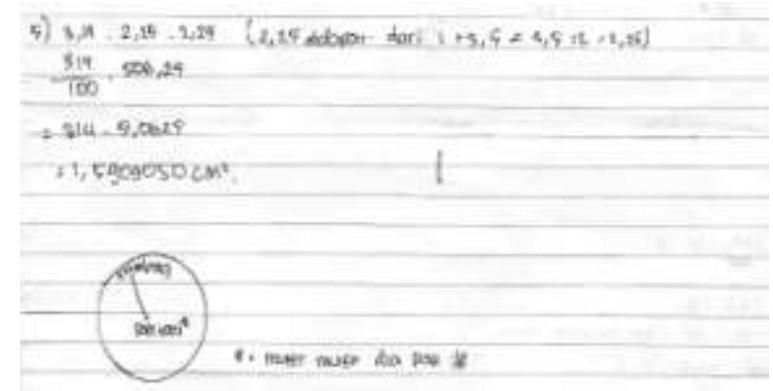

Gambar 10. Jawaban Siswa

Setelah siswa diberikan tes, dilakukan wawancara kepada guru dan siswa untuk mengetahui berbagai hambatan yang dihadapi dalam pelajaran matematika dan khususnya dalam menangani permasalahan matematika terbuka. Hasil wawancara yang dilakukan terhadap guru mata pelajaran matematika menunjukkan bahwa kendalah yang dihadapi guru dalam membelajarkan matematika di kelas adalah kurangnya pemahaman siswa yang mendalam terhadap permasalahan matematika sehingga saat siswa diberikan permasalahan no rutin siswa menjadi kebingungan padahal konsep yang digunakan masih sama. Sementara itu siswa menyatakan, kendala yang dihadapi adalah susahnya memahami maksud dari permasalahan matematika yang disajikan sehingga siswa jadi kesulitan dalam menentukan metode yang tepat untuk menyelesaikan permasalahan tersebut. Dalam menangani permasalahan matematika terbuka, siswa menyatakan sulit dalam melakukan reasoning dan memahami permasalahan. 
Selain itu, dilakukan pula observasi ke kelas oleh peneliti untuk melihat bagaimana pembelajaran matematika yang sudah berjalan selama ini. Peneliti menemukan jika pembelajaran matematika yang sudah berjalan masih terfokus pada aspek prosedural yaitu menekankan pada pemahaman dan pengunaan rumus dan tidak menekankan pada aspek berpikir kritis dan terbuka. Hal ini menjelaskan kenapa siswa sering kesulitan jika diberikan soal yang memanfaatkan kemampuan berpikir tingkat tinggi seperti permasalahan matematika terbuka.

\section{PENUTUP}

\section{Simpulan}

Dari tes, wawancara, serta observasi yang dilakukan, diperoleh beberapa kesimpulan yang menjadi kesulitan siswa dalam menangani permasalahan metamatika terbuka. Hal-hal tersebut antara lain:

1. Kurangnya pemahaman siswa terhadap permasalahan matematika terbuka sehingga siswa tidak dapat menentukan metode yang akan digunakan untuk menyelesaikan permasalahan tersebut.

2. Kurangnya kemampuan siswa dalam melakukan reasoning dimana siswa hanya melakukan reasoning yang tidak efektif seperti dengan cara coba-coba dalam menentukan ukuran.

3. Kesulitan siswa dalam menentukan metode lain yang dapat digunakan dalam menyelesaikan permasalahan. Hal ini dikarenakan siswa yang terbiasa mengikuti pembelajaran secara prosedural dengan hanya mengingat dan menerapkan rumus secara tepat tanpa memahami konsep secara menyeluruh.
4. Kurangnya kemampuan representasi dan berpikir secara riil siswa dalam menyelesaikan permasalahan agar siswa dapat memikirkan cara terbaik dalam menyelesaikan masalah matematika terbuka.

\section{Saran}

Saran yang dapat diberikan peneliti adalah agar guru-guru mata pelajaran matematika dapat menekankan pada aspek pemahaman konsep dan aspek pengembangan kemampuan berpikir dalam melakukan pembelajaran di kelas. Guru harus menitik beratkan pada bagaimana matematika dapat meningkatkan daya pikir siswa dan menghindari pembelajaran yang hanya sebatas prosedural saja. Hal ini akan membuat siswa dapat menangani permasalahan matematika terbuka dengan lebih baik karena kemampuan siswa dalam berpikir kritis dan terbuka sudah berkembang dan akan mengantarkan siswa dalam meningkatkan kemampuannya dalam bidang matematika.

\section{DAFTAR PUSTAKA}

Agung, A. A. Gede. (2014). Metode Penelitian Pendidikan. Malang: Aditya Media Publishing.

Bakker, A., \& Eerde, V. (2015). An introduction to design-based research with an example from statistics education. In A. BiknerAhsbahs, C. Knipping, \& N. Presmeg (Eds.), Approaches to Qualitative Research in Mathematics Education (pp. 429466). New York: Springer. doi:10.1007/978-94-017-91816_16.

Barab, S., \& Squire, K. (2004). Designbased research: Putting a stake in the ground. Journal of the Learning Sciences, 13, 1-14. 
doi:10.1207/s15327809j1s1301_1. Diakses tanggal 8 Juni 2015 pada http://www.didaktik.itn.liu.se/Tex ter/Barab_Squire_2004.pdf

Brousseau, G. (1997). Theory of didactical situations (N. Balacheff, $M$. Cooper, R. Sutherland, $V$. Warfield Eds \& Trans). Dordrecth. Netherland: Kluwer Academic.

Cifarelli, V. V., Cai, J. (2005). The Evolution of Mathematical Explorations in Open-Ended Problem Solving Situations. The Journal of Mathematical Behavior24(3), pp. 302-324.

Clarke, D., dkk. (1992). Student Response Characteristics to Open-Ended Tasks in Mathematical and Other Academic Contexts. Diakses tanggal 1 Oktober 2015 pada http://www.merga.net.au/docume nts/RP_Clarke_Sullivan_Spandel -1992.pdf

Dantes, N. (2012). Metode Penelitian. Yogyakarta: ANDI

Frambach, J. M., van der Vleuten, C. P., \& Durning, S. J. (2013). AM last page: Quality criteria in qualitative and quantitative design research. Academic Medicine, 88, 552.

Gravemeijer, K. (2004). Local instruction theories as means of support for teachers in reform mathematics education. Mathematical Thinking and Learning, 6, 105128.doi:10.1207/s15327833mtl06 02_3.

Lowrie, T., dkk. (2000). Knowledge and Strategies Students Employ to Solve Open-Ended ProblemSolving Activities. Diakses tanggal 1 Oktober 2015 pada http://www.merga.net.au/docume
nts/RP_Lowrie_Francis_Rogers 2000.pdf

Simon, M. A. (1995). Reconstructing mathematics pedagogy from a constructivist perspective. Journal for Research in Mathematics Education, 26, 114145.

Sudiarta, IGP. (2005). Pengembangan Kompetensi Berpikir Divergen dan Kritis Melalui Pemecahan Masalah Matematika OpenEnded. Diakses tanggal 5 Juni 2015 pada pasca.undiksha.ac.id/images/img item $/ 689$. doc

Sugiyono. (2013). Metode Penelitian Kuantitatif, Kualitatif, dan $R \& D$. Bandung: Alfabeta.

Sujarwo. (2013). Desain Sistem Pembelajaran. Diakses tanggal 16 November 2015 pada http://staff.uny.ac.id/sites/default/ files/penelitian/Dr.\%20Sujarwo, \%20M.Pd./Desain\%20Pembelajar an-pekerti.pdf

Sullivan, P., dkk. (2000). Students' Responses to Content Specific Open-Ended Mathematical Task. Diakses tanggal 1 Oktober 2015pada

http://citeseerx.ist.psu.edu/viewdo c/download?doi=10.1.1.466.3327 \&rep=rep1\&type $=$ pdf

Vui, T. (2014). Using Dynamic Visual Representations to Discover Possible Solutions in Solving Real-life Open-ended problems. International Conference on Research, Implementation and Education of Mathematics and Science (ICRIEMS), UNY: Yogyakarta. 